\title{
Impacted permanent maxillary incisors - clinical and therapeutic considerations
}

\author{
Incisivii maxilari permanenți incluși - considerații clinico-terapeutice
}

\author{
Mioara Decusară, Daniela Cornea, Cerasella-Dorina Șincar \\ Departamentul de Medicină Dentară, Facultatea de Medicină și Farmacie, \\ Universitatea „Dunărea de Jos“, Galați, România
}

\begin{abstract}
The frequency of impactation of the maxillary permanent incisors is low in dental practice, the orthodontist having the duty to determine the cause and establish and apply an orthodontic treatment as early as possible. The diagnosis of certainty of impactation of the permanent maxillary incisors is established when there is a delay in their eruption for about one year after the exfoliation of milky teeth. The interceptive and curative orthodontic treatment is important for facial aesthetics, for harmonious facial and skeletal development, for correcting possible malfunctions (phoniatric, masticatory, deglutition).
\end{abstract}

Keywords: impacted maxillary incisors, causes, clinical aspects, orthodontic treatment

\section{REZUMAT}

Frecvența incluziei incisivilor permanenți maxilari în practica stomatologică este redusă, medicul ortodont având datoria de a determina cauza și de a stabili și aplica un tratament ortodontic cât mai precoce. Diagnosticul de certitudine al incluziei incisivilor maxilari definitivi se stabilește atunci când există o întârziere a erupției acestora mai mult de un an după exfolierea celor de lapte. Tratamentul ortodontic interceptiv și curativ este important pentru estetica facială, pentru dezvoltarea scheletală facială armonioasă, pentru corectarea eventualelor malfuncții (fonatorii, masticatorii, deglutiție).

Cuvinte cheie: incisivi maxilari incluși, cauze, aspecte clinice, tratament ortodontic

\section{INTRODUCERE}

Dinții frontali maxilari (incisivii și caninii) sunt importanți pentru estetica faciala a oricărui individ, fiind vizibili atât în timpul zâmbetului, dar și al vorbirii. Absența unui incisiv poate determina tulburări funcționale (interferențe ocluzale și de dezvoltare scheletală facială, dificultăți la vorbire, masticație, deglutiție), dar mai ales probleme de comportament legate de interacțiunea cu persoane din diferite grupuri sociale, cu efect asupra încrederii în sine şi a stimei de sine (1).

Este necesară monitorizarea și stabilirea precoce a cauzei erupției întârziate a incisivilor maxilari definitivi, pentru a se interveni corect, atunci când este necesar. Sunt frecvente situațiile în care incisi- vii laterali erup înaintea centralilor, cu menținerea sau micşorarea spațiului necesar pentru erupția și alinierea incisivilor centrali, care rămân blocați (incluși) intraosos. Din grupul frontal incizal, incisivii centrali maxilari permanenți rămân incluși mai frecvent comparativ cu cei laterali (2).

Cauzele incluziei incisivilor maxilari permanenți pot fi $(1,3)$ :

- Prezența unor obstrucții patologice în calea de erupție a incisivilor: dinți supranumerari, odontoame, chisturi

- Malformații coronare și radiculare (dilacerația) ale incisivilor definitivi, apărute cel mai frecvent în urma unui traumatism al dintelui de lapte, cu afectarea mugurelui din- 
telui permanent supraiacent. Gradul de afectare a dintelui permanent depinde de gradul de dezvoltare a mugurelui dintelui în cauză, de direcția și amplitudinea traumatismului dentar.

- Poziţia ectopică a mugurilor incisivilor permanenți

- Persistența incisivilor de lapte în anchiloză osoasă

- Extracția sau exfolierea precoce a incisivilor de lapte, cu formarea unei bariere osoase și fibromucoase care se opune erupției celor definitivi

- Boli osoase, boli endocrine, boli genetice, malformații congenitale etc. (4).

- Pentru stabilirea diagnosticului clinic trebuie identificate următoarele elemente:

- Prezența unui dinte de lapte peste termenul de exfoliere, cu păstrarea sau nu a spațiului disponibil pentru erupția celui definitiv, când dintele contralateral este deja erupt și aliniat

- Palparea în vestibulul bucal sau în zona palatinală a coroanei dintelui definitiv presupus a fi inclus (palpare nedureroasă și necompresibilă) (4)

- Malpoziții ale dinților învecinați dintelui absent de pe arcadă (rotații sau înclinări) (5).

Diagnosticul de certitudine este dat de evaluarea radiologică, ortopantomograma fiind cea mai indicată, deoarece oferă, la o singură expunere, cu o doză de radiații reduse, o imagine de ansamblu a arcadelor dentare, poate arăta existența unui dinte inclus, gradul de resorbție a rădăcinii dintelui de lapte corespunzător şi profunzimea afectării (6). Telecefalografia de profil poate fi utilă în special dacă există un dinte supranumerar sau dilacerații prezente, deoarece permite vizualizarea și din normă laterală a unei eventuale patologii corelate cu dintele inclus. La examinarea radiografică, trebuie stabilite cu cât mai mare exactitate poziția și anatomia coroanei și dezvoltarea radiculară a dintelui inclus, apropierea de rădăcinile dinților vecini, orientarea tridimensională a axului lung al acestuia, prezența unui dinte supranumerar, odontoame, chisturi și legătura cu dintele inclus (2).

Tomografia computerizată cu con îngustat (CBCT) oferă informații tridimensionale extrem de detaliate ale dinților incluși, ale situației lor în raport cu obstacolele în calea de erupție, anatomia lor corono-radiculară, grosimea corticalei osoase vestibulare și palatinale, orice resorbție a dinților adiacenți sau pierderi osoase patologice, prezența sau absența unei linii radiotransparente continue între rădăcină și os (posibil anchiloză) (7).

După stabilirea diagnosticului final, trebuie elaborat un plan de tratament, coroborat cu situația clinică și radiologică existentă. În multe cazuri, nu este necesar un tratament „laborios“ cu excepția creării de spațiu care să permită incisivului maxilar inclus să erupă singur. Alte cazuri necesită intervenție chirurgicală și / sau ortodontică. Fiecare caz trebuie tratat independent pentru a formula planul de tratament adecvat și pentru a obține cel mai bun rezultat posibil pentru fiecare pacient (3).

Astfel, dacă un incisiv maxilar definitiv a rămas inclus din cauza lipsei de spațiu, se poate crea spațiu necesar erupției spontane a acestuia (mai ales când rădăcina este în formare sau apexul nu este închis) cu ajutorul unui aparat ortodontic mobilizabil sau al unui disjunctor. Dacă există un capac osos sau fibromatos care împiedică erupția spontană, atunci trebuie efectuată o intervenție chirurgicală prin care să se îndepărteze aceste cauze (1).

Tratament chirurgical trebuie instituit și în situațiile în care există alte obstacole în calea de erupție a incisivului maxilar permanent (dinte supranumerar, chist, odontom) cu sau fără menținerea spațiului necesar erupției. De cele mai multe ori, se asociază și un tratament ortodontic, fiindcă dintele inclus trebuie ,ajutat“ prin forțe ortodontice să-și reinițieze potențialul de erupție și să fie aliniat corect pe arcada dentară. Există posibilitatea ca un incisiv maxilar în erupție să rămână anchilozat la un moment dat în timpul procesului de erupție. În aceste situații, se poate încerca luxația chirurgicală a dintelui anchilozat, menținând în același timp alimentarea periapicală cu sânge, având ca rezultat o reacție inflamatorie care poate determina formarea unui nou ligament fibros, cu aplicarea imediată a forțelor ortodontice pentru a preveni reapariția anchilozei $(2,4)$.

În cazul unui dinte dilacerat, este posibil ca porțiunea radiculară orientată vestibular să fie afectată pe osul cortical, fiind astfel indicată extracția incisivilor dilacerați, cu indicația evitării traumatizării dinților învecinați în timpul îndepărtării, precum şi a pierderii osului alveolar care ar putea afecta negativ posibilitățile viitoare de tratament, cum ar fi 
închidere spațială ortodontică, înlocuirea incisivului maxilar cu un implant sau lucrare protetică (8).

\section{SCOP}

În lucrarea de față, ne propunem să subliniem câteva elemente privind clinica incisivilor maxilari permanenți incluşi, metodele de evaluare radiologică pentru stabilirea diagnosticului de certitudine, precum și terapia ortodontică și chirurgicală de corectare.

\section{MATERIAL ŞI METODĂ}

Spre exemplificare, am ales trei cazuri clinice, respectiv trei adolescenți cu probleme estetice dentare la arcada superioară, datorate incluziei incisivului central maxilar permanent.

\section{PREZENTAREA CAZURILOR}

Un prim caz este un băiat de 13 ani, S.E., a cărui mamă a solicitat consult ortodontic fiind îngrijorată de întârzierea în erupție a 21, după exfolierea fiziologică a lui 61 în urmă cu aproximativ 2 ani.

a examenul clinic intraoral, pacientul prezenta (fig. 1):

- dentiție definitivă cu absența lui 21 și menținerea spaţiului pentru erupție

- relații neutrale la nivel canin și molar, bilateral

- supraacoperire frontală de $2 / 3$, cu menținerea corespondenței între liniile mediane și interincisive

- înghesuire dento-alveolară mandibulară de aproximativ $3 \mathrm{~mm}$, cu angrenaj lingualizat între 14 și 44

- palparea unei bombări în vestibulul bucal din dreptul spaţiului pentru 21.
Ortopantomograma (fig. 2) a arătat prezența unui supranumerar între 21 și 22 , care a determinat mezioînclinarea coronară intraosoasă a lui 21 , care a rămas inclus. De asemenea, s-a observat blocarea în erupție a lui 27 de către alt supranumerar, situat distal de 26, precum și prezența mugurilor celor patru molari de minte, în stadiul de mineralizare coronară, cu spațiu redus pentru erupție.

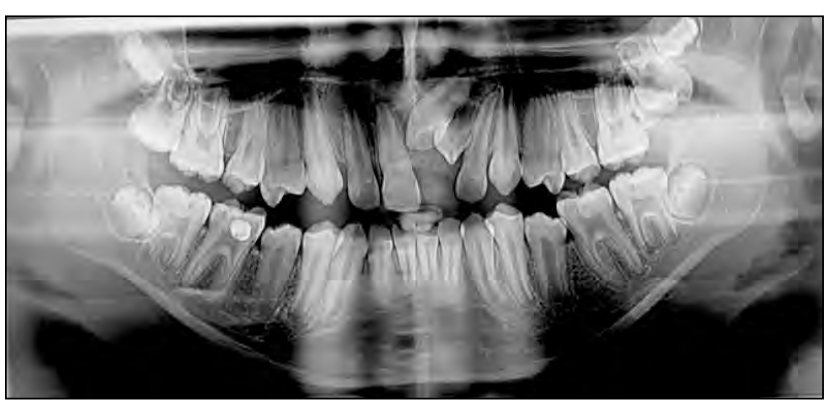

FIGURA 2. Imaginea panoramică a arcadelor dentare înainte de tratamentul chirurgical-ortodontic

Planul de tratament propus și acceptat de pacient și mamă a constat în:

- Aplicarea unui aparat ortodontic fix maxilar, pentru nivelare și alinierea arcadei dentare superioare și crearea de spațiu suplimentar pentru erupția lui 21

- Extracția dinților supranumerari și descoperirea chirurgicală a coroanei lui 21 , cu aplicarea unui ataș ortodontic pentru tracționarea acestuia spre locul de erupție (fig. 3)

- Aplicarea aparatului fix mandibular pentru aliniere dentară, deblocarea angrenajului lingualizat lateral dreapta între 14 și 44 și reducerea supraacoperirii frontale

După încă 14 luni de tratament ortodontic, a fost îndepărtat aparatul ortodontic fix bimaxilar, s-a efectuat detartraj subgingival și periaj profesional și s-au aplicat aparate de contenție tip gutieră, cu indicația de purtare pe timp de noapte (fig. 4).
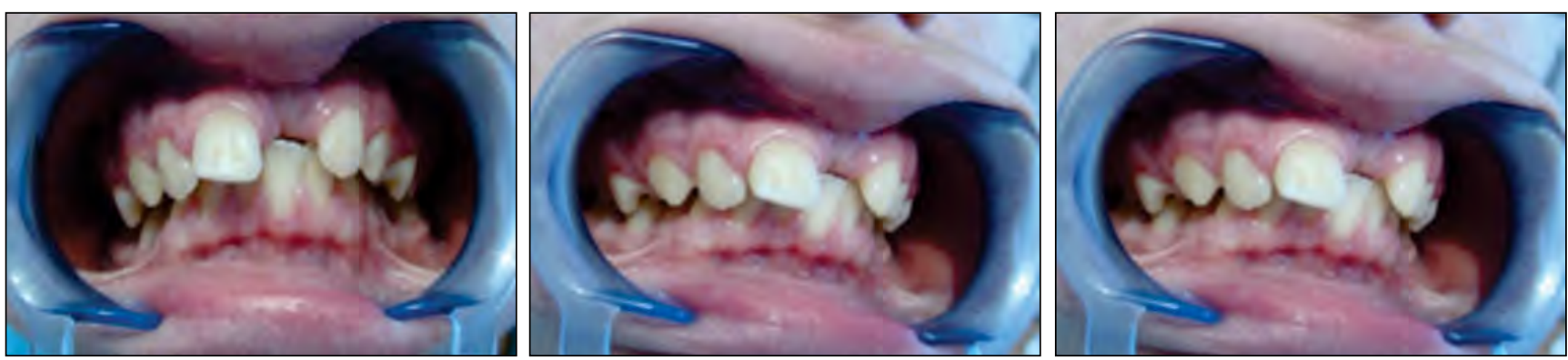

FIGURA 1. Aspectul arcadelor dentare înaintea începerii tratamentului ortodontic 

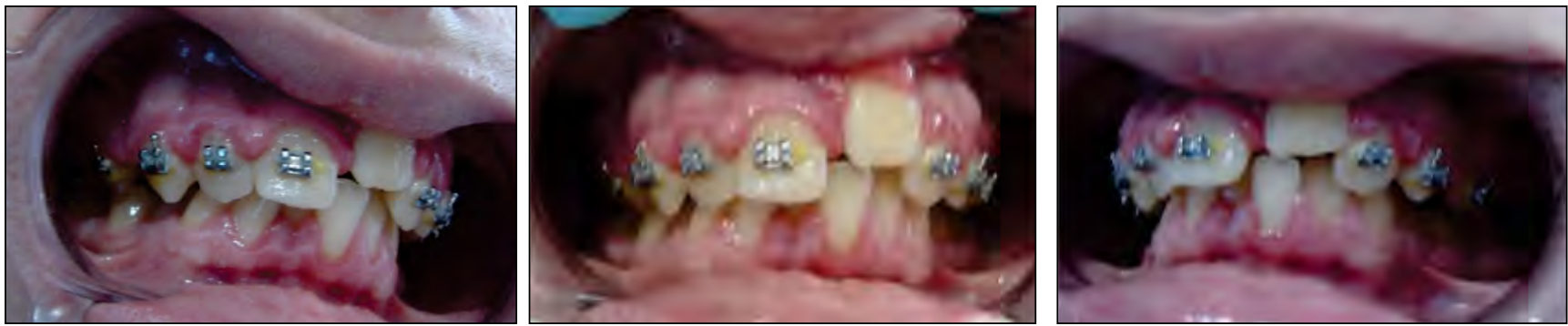

FIGURA 3. Imaginea arcadelor dentare la un an de la începutul tratamentului ortodontic, înainte de aplicarea aparatului fix la arcada dentară mandibulară
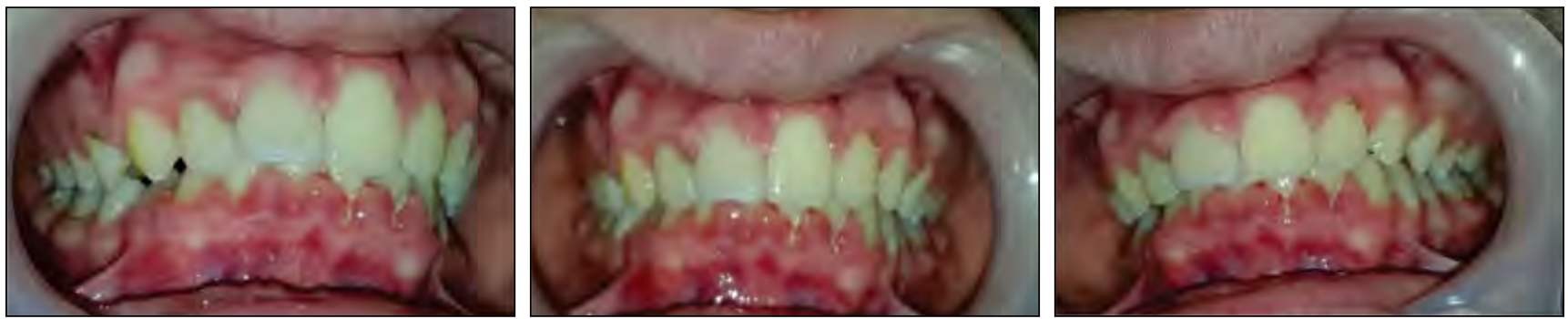

FIGURA 4. Aspectul arcadelor dentare după îndepărtarea aparatelor ortodontice fixe

La controlul efectuat la 9 luni de la finalizarea tratamentului ortodontic, s-a observat menținerea rezultatelor, ocluzie stabilă neutrală și igienă dentară bună, fără prezența fenomenelor inflamatorii gingivale (fig. 5).

Un alt caz este al pacientului I.N., de 13 ani, care prezenta dentiție definitivă, cu molarii secunzi definitivi în erupție și absența de pe arcadă a lui 21, cu spațiu redus pentru erupție și aliniere. Mama băiatului a declarat că incisivul de lapte a fost extras în urmă cu 1 an și, observând că cel permanent nu erupe, deși în vestibulul bucal se observa și palpa prezența coroanei unui dinte, a solicitat consult ortodontic (fig. 6).

Ortopantomograma efectuată în urmă cu trei ani, datorită persistenței lui 61, a arătat incluzia lui 21 prin prezența unui meziodens situat între rădăcina lui 61 și coroana lui 21 , cu rădăcina în distoînclinare (fig. 7).

S-a aplicat aparat ortodontic fix la arcada superioră pentru aliniere dentară și creare de spațiu necesar pentru erupția lui 21. După două luni de la
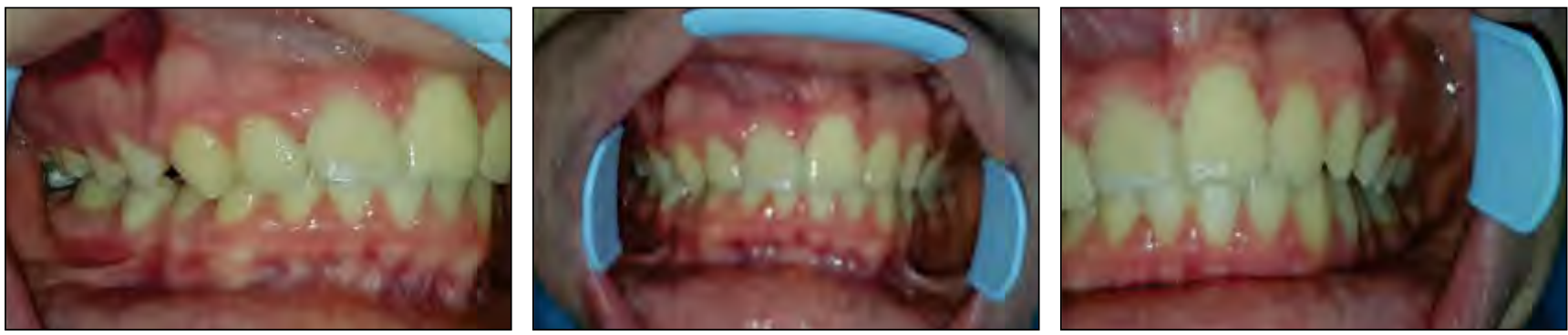

FIGURA 5. Aspectul arcadelor dentare la 9 luni de la finalizarea tratamentului ortodontic
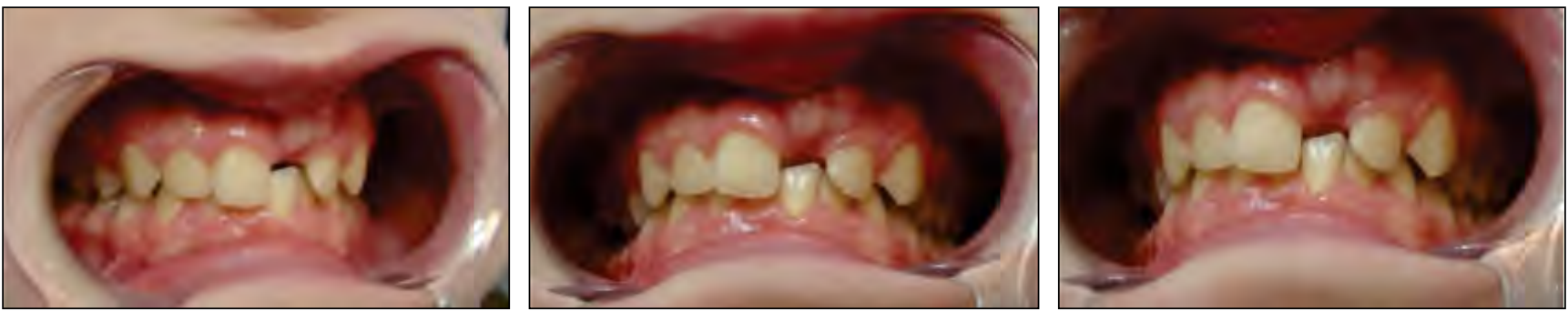

FIGURA 6. Ocluzia statică şi aspectul arcadelor dentare ale pacientului I.N., de 13 ani 


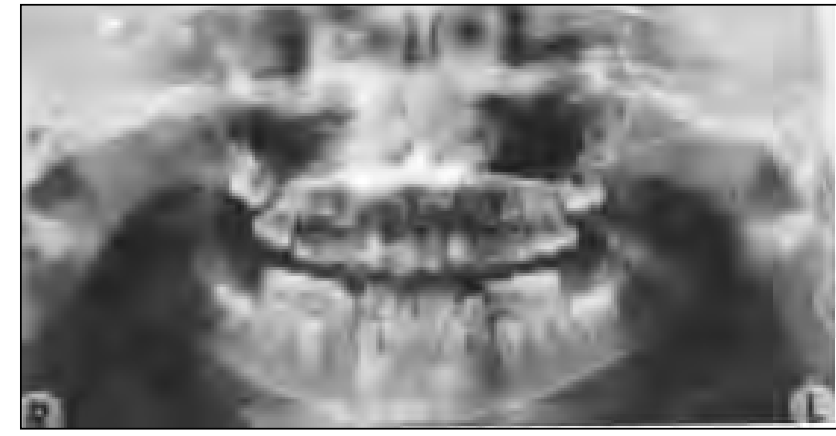

FIGURA 7. Ortopantomograma pacientului I.N. arată prezența unui supranumerar, cu coroana mineralizată, ce a determinat rizaliza lui 61 şi incluzia lui 21

începerea tratamentului ortodontic, s-a îndepărtat meziodensul şi s-a descoperit chirurgical coroana lui 21, cu aplicarea unui ataş ortodontic cu tracțiune elastică pentru stimularea erupției acestuia și alinierea pe arcadă (fig. 8).

După 24 luni de tratament ortodontic activ, a fost îndepărtat aparatul ortodontic fix, contenția fiind realizată cu o placă palatinală tip Hawley, cu recomandarea purtării pe timp de noapte (fig. 9).
Un ultim caz este al pacientului L.A., de 15 ani, care a solicitat un consult ortodontic, din cauza întârzierii în erupție a lui 11 și a lui 13.

La examenul endobucal, s-au semnalat următoarele (fig. 10):

- dentiție definitivă indemnă cu absența lui 11 și bombarea versantului vestibular al crestei alveolare din dreptul acestuia

- absența lui 13, fără spațiu pentru erupție și aliniere

- fren labial superior cu baza de implantare în vecinătatea papilei interincisive

- raporturi neutrale la nivelul molarilor și la nivel canin de partea stângă și cu raport fals clasa a III-a la nivel canin de partea dreaptă (prin distalizarea lui 12).

Pe radiografia retrolaveolară efectuată pentru 11, cu care s-a prezentat pacientul la consult, s-au evidențiat următoarele:

- 11 inclus, cu prezența unui chist folicular în jurul coroanei acestuia, cu marginea inferioa-
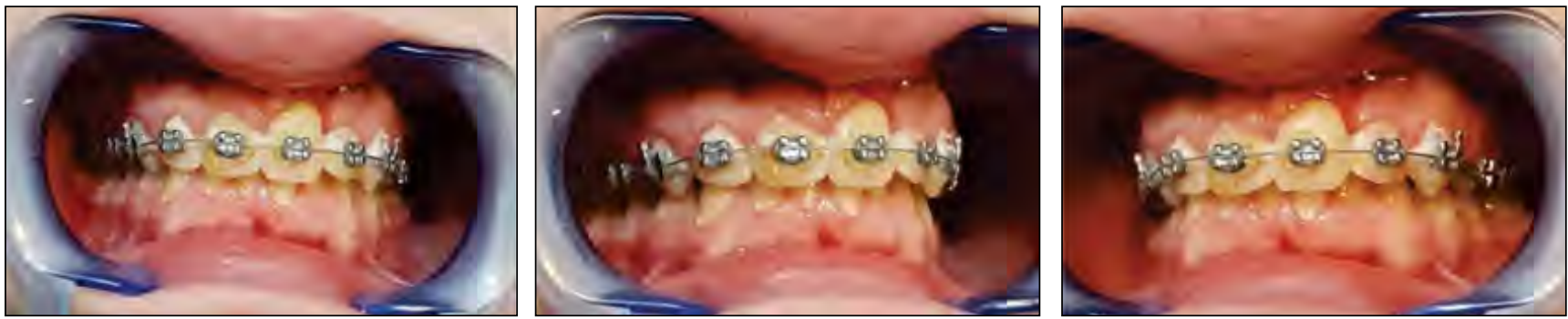

FIGURA 8. Aspectul arcadelor dentare la 18 luni de la începutul tratamentului ortodontic
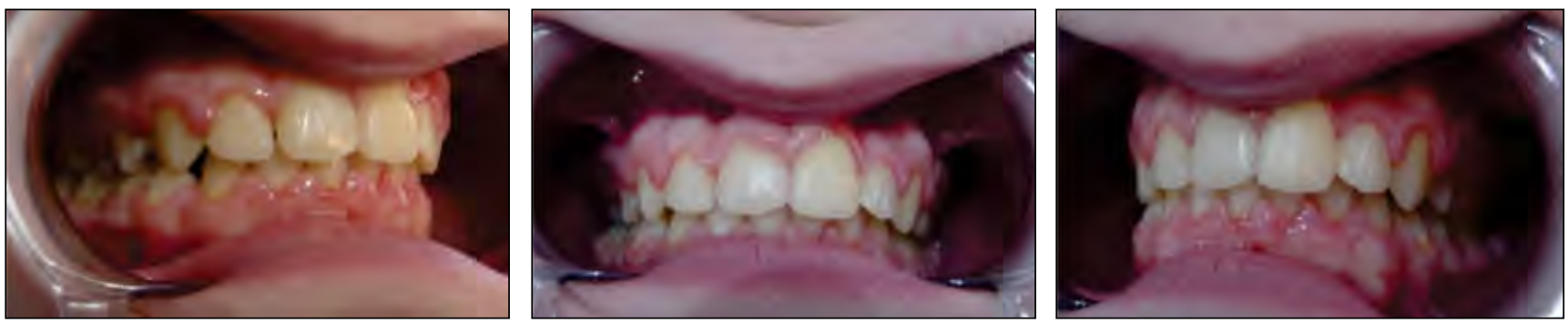

FIGURE 9. Ocluzia statică şi aspectul arcadelor dentare la finalul tratamentului ortodontic
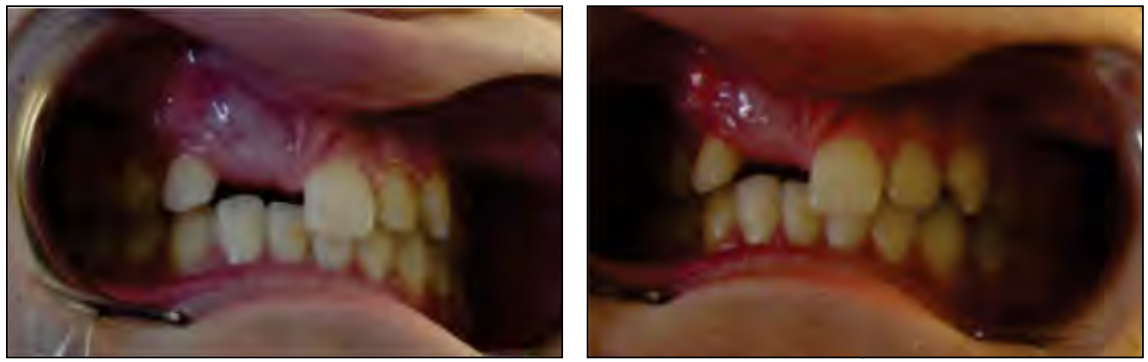

FIGURA 10. Aspectul ocluziei statice a pacientului L.A., la începutul tratamentului ortodontic 


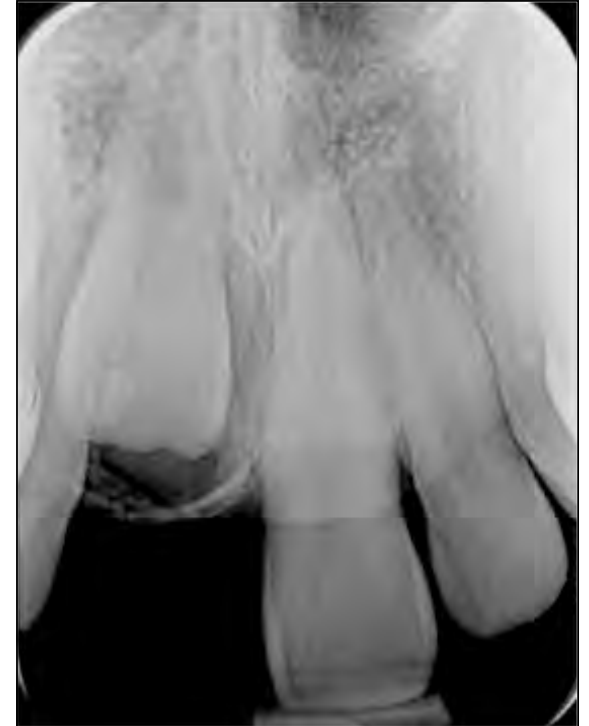

FIGURA 11. Radiografia retroalveolară pentru 11

ră în imediata vecinătate a corticalei alveolare (chist care a determinat distalizarea lui 12 și blocarea erupției lui 13)

- o formațiune radioopacă mică, în dreptul marginii incizale a dintelui inclus (cu aspectul unei perle de smalţ).

Pentru stabilirea unui diagnostic corect și a unui plan de tratament ortodontico-chirugical, s-a reco- mandat efectuarea unui examen radiografic de tip tomografie computerizată cu fascicul conic (CBCT) (fig. 12). Astfel, au fost evidențiate următoarele elemente patologice:

- 13 inclus în poziție vestibulară

- 11 inclus și formațiune chistică în jurul coroanei acestuia

- prezența unei formațiuni radioopace mici (posibil odontom), de aproximativ $1 \mathrm{~mm}$, înapoia coroanei lui 11 (care, la radiografia retroalveolară, prin suprapunerea peste imaginea coronară a lui 11, lăsa impresia unei perle de smalț).

Planul de tratament ortodontico-chirurgical a constat în (fig. 13):

- aplicare de aparat fix la maxilarul superior pentru nivelare și aliniere dentară

- $\quad$ chistectomie și descoperirea chirurgicală a coroanei lui 11, cu aplicare de ataș ortodontic cu ligatura elastică pentru tracționare și aliniere

- creare de spațiu pentru erupția și alinierea lui 13

- aplicare de aparat ortodontic fix la arcada mandibulară pentru aliniere, corectarea
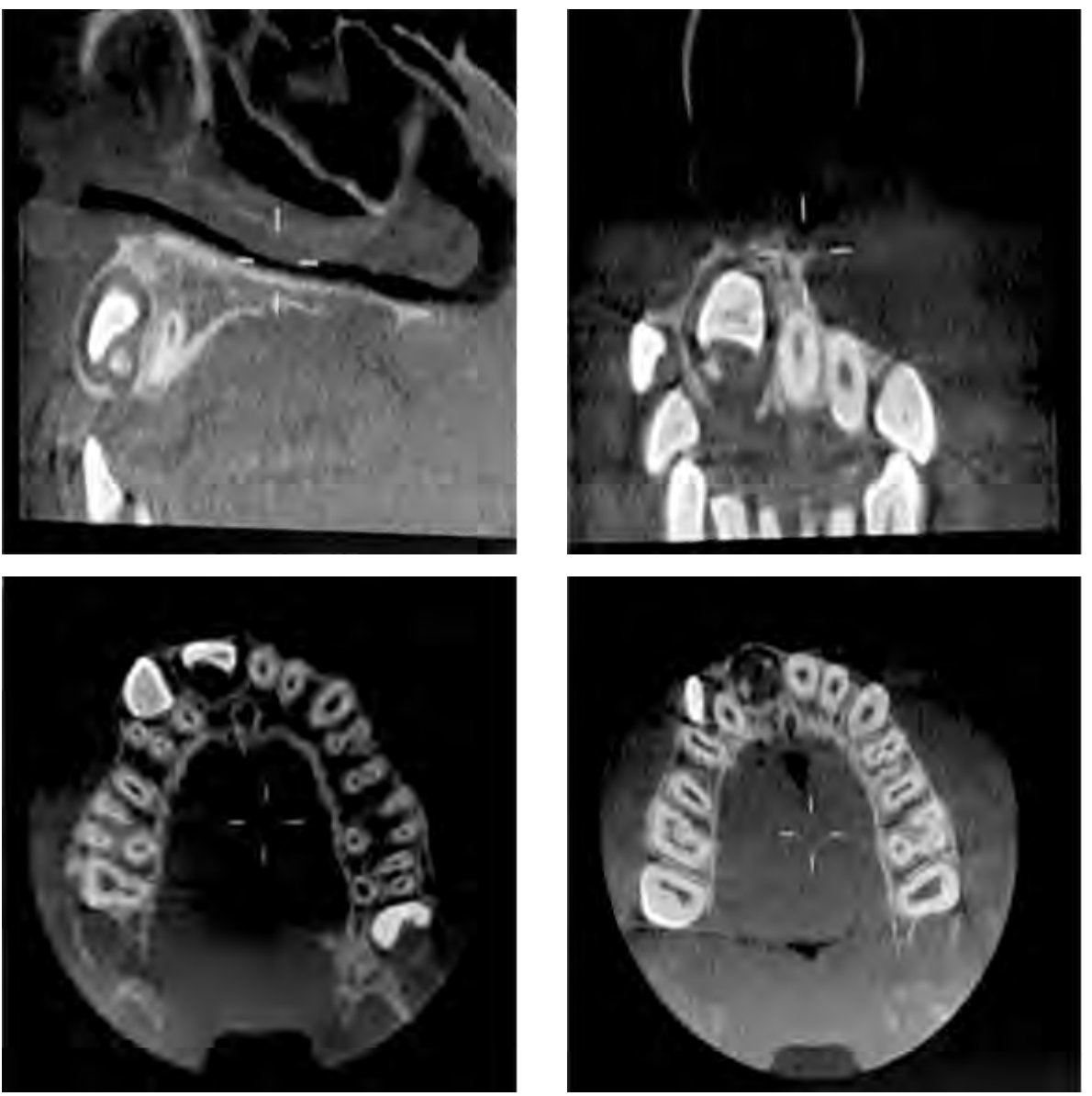

FIGURA 12. Imaginea

tridimensională a lui 11 şi 13 incluşi, formațiune chistică din jurul coroanei lui 11 şi prezența unei mici formațiuni radioopace în cavitatea chistică 

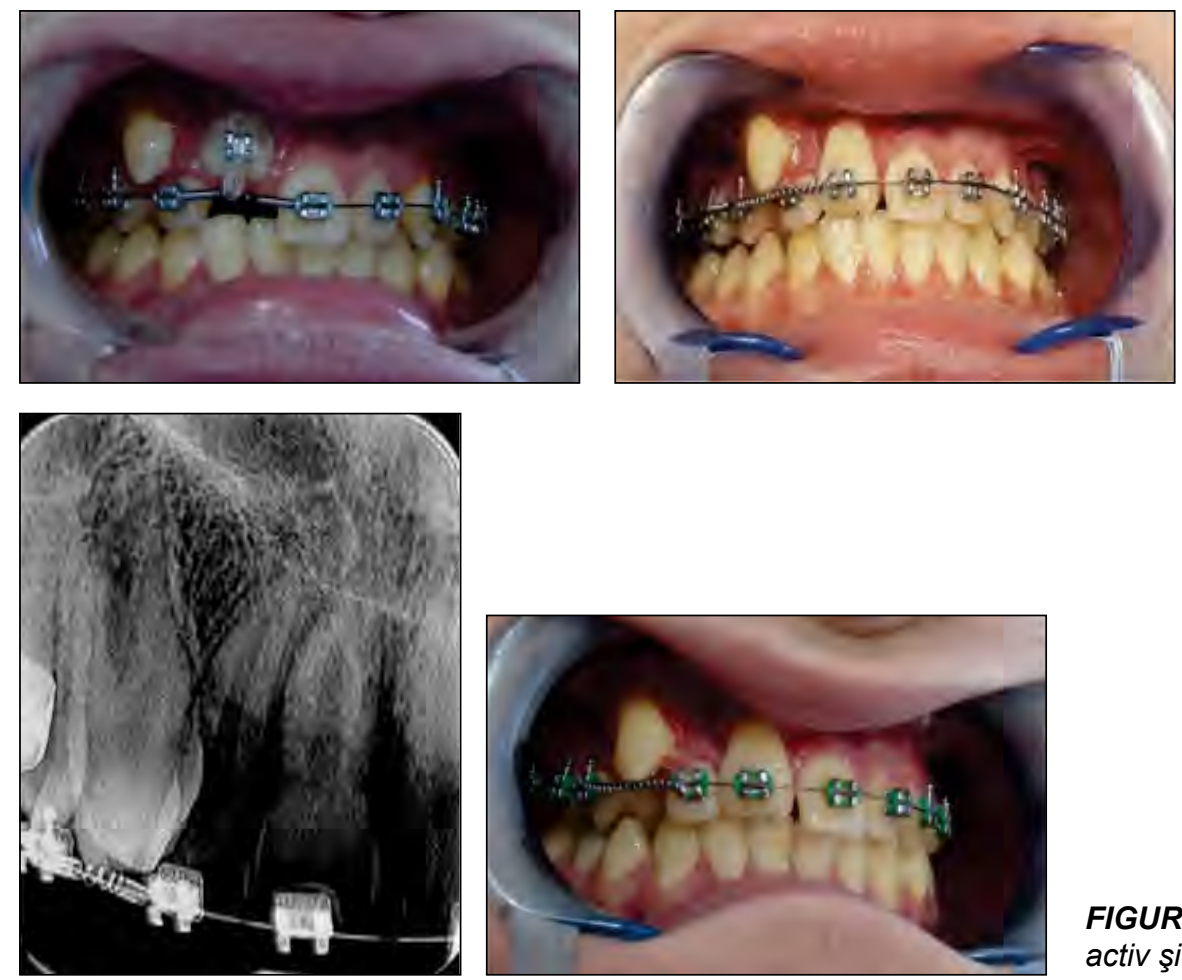

FIGURA 13. Etape ale tratamentului ortodontic activ şi control radiografic pentru 11 şi 13

malpozițiilor dentare și obținerea relațiilor ocluzale neutrale în sens sagital, transversal și vertical.

Aparatul ortodontic fix bimaxilar a fost îndepărtat după 32 luni, cu indicația purtării unor aparate de contenție de tip gutiere, control periodic la 6-8 luni și dispensarizarea erupției molarilor de minte (fig. 14).

\section{REZULTATE ŞI DISCUȚII}

Pentru a trata corect pacienții cu incisivi maxilari permanenți incluși, medicul ortodont trebuie să cunoască etiologia și modalitățile de diagnosticare și de tratament disponibile pentru tulburările de erupție ale acestora. Este important să se efectueze o examinare amănunțită clinică și radiologică pentru a obține un diagnostic precis.
În literatura de specialitate sunt prezentate abordări diferite privind tratamentul incisivilor maxilari incluși, esențial fiind diagnosticul precoce care să asigure succesul tratamentului ortodontic. $\mathrm{Cu}$ cât erupția normală este mai puțin întârziată, cu atât rezultatul este mai bun (ținând cont de gradul de formarea radiculară). Dacă a existat o pierdere de spațiu, este necesar să se creeze spațiu cu un aparat ortodontic și să se mențină acest spațiu până erupe dintele incisivul definitiv.

Atunci când este semnalată o cauză care împiedică erupția unui incisiv maxilar permanent inclus, trebuie înlăturată obstrucția, trebuie creat spațiul necesar erupției și monitorizată erupția spontană, care se poate produce fără un tratament ortodontic suplimentar (9). În cazul prezenței unui dinte supranumerar, acesta trebuie îndepărtat, evitând deteriorarea incisivului definitiv inclus, cu sau fără
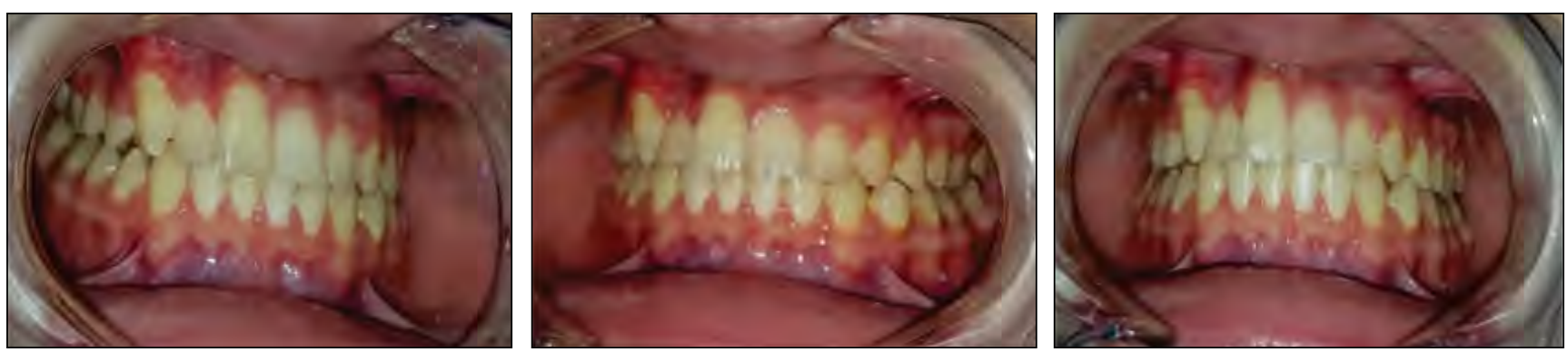

FIGURA 14. Aspectul ocluziei statice şi al arcadelor dentare la finalul tratamentului ortodontic 
aplicare ulterioară a unei tracțiuni ortodontice. Sunt situații în care incisivii maxilari definitivi incluși necesită tratament chirurgical ortodontic etapizat astfel: aplicarea de aparat ortodontic pentru crearea de spațiu pentru dintele inclus, tratament chirurgical prin care se înlătură obstrucția patologică, cu descoperirea chirurgicală a dintelui inclus, apliacrea unui ataș ortodontic pentru aplicarea unei tracțiuni ortodontice, cu erupția și alinierea pe arcadă a acestuia $(2,4)$.

\section{BIBLIOGRAFIE}

1. Smailiene D, Sidlauskas A, Bucinskiene J. Impaction of the central maxillary incisor associated with supernumerary teeth: initial position and spontaneous eruption timing. Stomatologija. 2006;8(4):103-107.

2. Becker A. The orthodontic treatment of impacted teeth. 1998.

3. Chokron A, Reveret S, Salmon B, Vermelin L. Strategies for treating an impacted maxillary central incisor. Int Orthod. 2010 Jun;8(2):152176.

4. Smailiene D, Sidlauskas A, Bucinskiene J. Impaction of the central maxillary incisor associated with supernumerary teeth: Initial position and spontaneous eruption timing. Stomatologija. 2006;8(4):103-107.

5. Mioara Decusară. Utilizarea ortopantomogramei în practica stomatologică. Ed. Zigotto, 2017, Galați, ISBN: 978-606-669-263-2.

\section{CONCLUZII}

Tratamentul ortodontic interceptiv și curativ este important pentru estetica facială, pentru dezvoltarea scheletală facială armonioasă, pentru corectarea eventualelor malfuncții (fonatorii, masticatorii, deglutiţie).

6. Mioara Decusară, Gabriel Valeriu Popa, Cerasella Dorina Șincar. The relevance of orthopantomograms use in orthodontic practice. $J$ Med Res Prac, 2017, 6(6): 189-194.

7. Chaushu S, Chaushu G, Becker A. The role of digital volume tomography in the imaging of impacted teeth. World J Orthod. 2004;5(2):120-132.

8. Jena AK. Duggal R. Roychoudhury A. Parkash H. Orthodontic assisted tooth eruption in a dentigerous cyst: A case report. J Clin Pediatr Dent 2004;29: 33-35.

9. Mioara Decusară, Dorina-Cerasella Șincar, Gabriel Valeriu Popa. Aspecte clinico-terapeutice în incluzia dentară. Revista Română de Stomatologie, 2017, 63(3): 124-128. 